\title{
Photo-aging regulation effects of newly bred Green ball apple
}

\author{
Eun-Ho Lee ${ }^{1} \cdot$ Seung-Yeol Lee ${ }^{2} \cdot$ Hee-Young Jung ${ }^{2} \cdot$ In-Kyu Kang $^{3} \cdot$ Dong-Hyun Ahn ${ }^{4} \cdot$ Young-Je Cho $^{1}$ (D)
}

\section{신품종 그린볼 사과의 광노화인자 조절효과}

이은호 ${ }^{1}$ - 이숭열 ${ }^{2} \cdot$ 정희영 ${ }^{2} \cdot{\text { 강인 }^{3}}^{*}$ 안동현 $^{4} \cdot$ 조영제 $^{1}$

\begin{abstract}
In this study, extracts from the Green ball apple peel (GBE) and the newly bred green ball apple from Korea showed inhibition effects on photo-aging factor regulation associated with skin aging. To investigate the inhibition effect on photo-aging factor regulation in skin, GBE was treated with UVB to induce photo-aging related factors in CCD986sk fibroblast cells. Photoaging factor regulation effects showed that GBE inhibited UVBstimulated matrix metalloproteinase (MMP)-1 and MMP-9 protein synthesis in collagen type I alpha 2 chain (COL1A2), MMP-1, MMP-9, and tissue inhibitors of metalloproteinase (TIMP)-1 protein expression. The expression of COL1A2 and TIMP-1 protein was significantly increased. The mRNA expression levels of COL1A2, MMP-1, MMP-9, hyaluronan synthase (HAS)2, transforming growth factor (TGF)- $\beta$, and TIMP-1 were decreased by GBE. The expression of TIMP- 1 and TGF- $\beta$, which are regulators involved in matrix metalloproteinase and type I pro-
\end{abstract}

Young-Je Cho $(\bowtie)$

E-mail:yjcho@knu.ac.kr

${ }^{1}$ School of Food science \& Biotechnology, Kyungpook National University, 80 University Street, Bukgu, Daegu 41566, Republic of Korea

${ }^{2}$ School of Applied Biosciences, Kyungpook National University, 80 University Street, Bukgu, Daegu 41566, Republic of Korea

${ }^{3}$ Department of Horticultural Science, Kyungpook National University, 80 Daehakro, Bukgu, Daegu 41566, Republic of Korea

${ }^{4}$ Department of Food Science and Technology, Pukyong National University, Busan 48513, Republic of Korea

This is an Open Access article distributed under the terms of the Creative Commons Attribution Non-Commercial License (http://creativecommons. org/licenses/by-nc/3.0/) which permits unrestricted non-commercial use, distribution, and reproduction in any medium, provided the original work is properly cited. collagen expression, was found to increase with increasing expression of COL1A2. The expression of HAS2, which is involved in the production of hyaluronic acid, one of the structural proteins constituting the skin, was also confirmed. Therefore, GBE showed excellent efficacy against photo-aging factor regulation and could be used as functional material to prevent and treat skin aging.

Keywords CCD986sk fibroblast cells · Extracts · Green ball · Newly bred apple $\cdot$ Photo-aging

\section{서 론}

인체의 장기 중 최외각에 위치한 피부는 우리 몸의 항상성을 저해하는 외부 인자의 침입을 막아주는 일차적인 보호기관이다. 피부는 외부의 화학적, 물리적, 생물학적 장벽기능을 수행하고 있으나 다양한 환경적 요인과 접촉하고 있기 때문에 손상을 받 기 쉽다[1,2]. 피부 노화는 크게 내인성 노화와 외인성 노화로 구분되는데, 시간적유전적 요소에 의해 발생되는 전자와 달리 후자인 외인성 노화는 자외선(ultraviolet; UV) 노출, 대기 오염, 흡연, 알코올 남용, 영양 부족 등 외부 환경에 의한 것으로 알 려지고 있다[3,4]. 이러한 환경 요인 중 $\mathrm{UV}$ 에 의한 광노화 (photo aging)는 피부 노화, 특히 조기 노화에서 중요한 원인으 로 작용하기에 관리가 필요하다[3,5].

광노화에 따른 주요 피부 변화는 주름증가, 피부 두께 및 탄 력 감소가 대표적이며, 이러한 피부 변화는 UV로 인해 섬유성 단백질의 생산, 피부 탄력, 주름 또는 잔주름 억제에 관여하는 세포외기질(extracellular matrix)이 분해되고, 이를 생산하는 섬 유아세포의 활성이 저하되어 collagen 생합성이 감소하고 변성 된 elastin이 증가하게 된다. 또한 활성화된 activator protein 1 
에 의해 세포외기질을 분해하는 matrix metalloproteinase (MMPs) 의 발현이 유도된다. 유도된 MMPs에 의해 collagen, elastin 등 의 기질 분해가 증가되고 진피 내 UV에 의한 열상이 발생하게 되며, 표피-진피 경계부가 파괴되어 진피 분해가 가속화되어 피 부가 얇아지고, 탄력이 감소하여 주름 증가와 피부의 건조증상 이 심해져[6], 기미, 주근깨 및 검버섯 등이 생성되는 광노화가 진행된다[7,8].

사과나무(Malus pumila Mill.)는 분류학상 장미과에 속하는 다년생 목본식물로서 유럽, 아시아 및 북아메리카의 북반구에서 재배된다[9-12]. 사과 과실은 관능특성이 좋고 영양학적으로 유 기산과 당류와 같은 기호성 성분 이외에도 비타민, 미네랄, 칼 륨, 나트륨 성분 및 폴리페놀화합물과 같은 생리활성물질들을 함유하고 있다. 사과의 과육과 껍질에는 폴리페놀화합물과 같은 생리활성물질들(procyanidin, chlorogenic acid, caffeic acid, epicatechin, catechin, p-coumaroyl qunic acid, rutin, phloridzin, quercetin etc.)[12,13]이 다량 함유되어 있어 내인성, 외인성 노 화 또는 산화적 손상에 의한 피부노화, 염증, 암 등과 같은 질 병에 대한 억제와 예방에 밀접한 관련이 있다. 실험에 이용한 신육성품종 그린볼 사과는 경북 군위군 소재의 사과연구소에서 교배조합으로 골든데리셔스(Golden delicious; 모본)와 후지 (Fuji; 부본)를 이용해 교배하여 육종 개발되었다. 그린볼 사과 는 붉은색 사과와 차별화를 가진 틈새시장형 녹황색 사과 품종 으로, 과실 특성은 성숙기는 9월 상순이며, 과형은 편원추형, 과 피색은 녹황색, 과중은 약 $327 \mathrm{~g}$, 과육의 경도는 $3.2 \mathrm{~kg} / \phi 8 \mathrm{~mm}$, 당도는 $14.0{ }^{\mathrm{o}} \mathrm{Bx}$, 그리고 산도는 $0.4 \%$ 정도이다. 2011년 국립 종자원에 품종 등록 완료되었으며, 과일이 녹황색인 장점을 살 려 시장진출을 목표로 재배하는 품종이다.

본 실험에서는 신육성품종 그린볼 사과 껍질의 주름개선 효 능을 확인하고 광노화 인자 억제 효과를 검정함으로서 기능성 소재로서 개발을 시도하였다.

\section{재료 및 방법}

\section{시험 재료 및 추출물의 제조}

본 연구에서 사용된 시험 재료인 그린볼 사과는 경북 군위군 소재의 사과연구소에서 재배되고 있는 그린볼 사과 나무로부터 9월에 완숙한 사과를 수확한 후 이물질을 제거하고 동결건조 (freeze dryer, FD8518, Ilshinbiobase, Yangju, Korea)하여 수분 을 제거한 후 $40 \mathrm{mesh}$ 로 분쇄하였다. 분쇄한 사과 분말과 ethanol 용액을 일정 비율 (1:100)로 첨가하여 $4{ }^{\circ} \mathrm{C}$ 의 shaking incubator에서 24시간 동안 교반 추출한 후 Whatman No. 1 filter paper (Whatman inc., piscataway, New jersey, USA)로 여과한 샘플을 다시 동결건조하여 $4{ }^{\circ} \mathrm{C}$ 또는 $-20{ }^{\circ} \mathrm{C}$ 시료보관 냉장고에서 저온 보관하며 실험에 사용하였다.

\section{세포 배양}

American Type Culture Collection에서 CCD-986sk (Human fibroblasts) 세포를 구매하였다. 세포는 Iscove's Modified Dulbecco's Medium (HyClone Laboratories, Inc, Logan, Utah, USA)에 10\% fetal bovine serum (HyClone Laboratories, Inc.)
과 $1 \%$ penicillin-streptomycin (HyClone Laboratories, Inc.)을 첨가한 배지를 배양액으로 $37^{\circ} \mathrm{C}, 5 \% \quad \mathrm{CO}_{2}$ incubator (311, Thermo Fisher Scientific, Waltham, MA, USA)에서 배양하였 다. 실험과정의 모든 세포는 $80-90 \%$ 정도의 밀도로 자랐을 시 계대배양을 실시하였고, 20 passages를 넘기지 않은 세포만 사 용하였다.

\section{Fibroblast cell line MTT assay}

$\mathrm{GBE}$ 와 정제물의 세포독성을 평가하기 위해 Carmichael 등의 방법[14]에 준하여 MTT assay를 실시하였다. CCD986sk 세포 $\left(5 \times 10^{4}\right.$ cells $\left./ \mathrm{mL}\right)$ 를 96 well plate에 분주하고 $5 \% \mathrm{CO}_{2}$ incubator (311, Thermo Fisher Scientific)에서 24시간 배양 후, 추출물과 정제물을 농도별로 첨가하여 48시간 배양하였다. 배양 후, 5 $\mathrm{mg} / \mathrm{mL}$ 농도로 제조한 MTT (Sigma-Aldrich Co., Louis, MO, USA) 시약을 $20 \mu \mathrm{L}$ 를 첨가하여 4시간 재 배양한 후 배양액을 제거하고 각 well에 dimethyl sulfoxide (DMSO) $200 \mu \mathrm{L}$ 를 가 하여 실온에서 10 분간 반응 시킨 뒤 enzyme-linked immunosorbent assay reader (SPECTRO star Nano, BMG LABTECH, Ortenberg, Germany)로 $540 \mathrm{~nm}$ 에서 흡광도를 측정하였다. Cell viability (\% of control)는 (sample absorbance/control absorbance) $\times 100$ 으로 나타내었다.

\section{Western blot을 이용한 COL1A2, MMP-1, MMP-9, TIMP- 1 protein 발현량 측정}

UVB로 자극된 CCD986sk 세포의 COL1A2, MMP-1, MMP-9, TIMP-1 protein 발현량 측정은 6 well plate에 $1 \times 10^{5}$ cells $/ \mathrm{mL}$ 이 되도록 분주하고 $5 \% \mathrm{CO}_{2}$ incubator (311, Thermo Fisher Scientific)에서 24시간 배양하고, 무혈청 배지로 교환한 후, 5시 간 이상 cell starvation하였다. 세포에 UVB 조사 시스템 (BioLinkCrosslinker; VilberLourmat, Torcy, France)으로 UVB (24 $\mathrm{mJ} / \mathrm{cm}^{2}$ ) 자극과 추출물과 정제물을 농도별로 처리하여 48 시간 재 배양하고 phosphate-buffered saline (PBS)로 세척하였다. MPER (Thermo Fisher Scientific)와 protease inhibitor (Thermo Fisher Scientific)를 섞은 mixture를 각 well당 $70 \mu \mathrm{L}$ 첨가하여 $4{ }^{\circ} \mathrm{C}$ 에서 lysis시킨 후, $4{ }^{\circ} \mathrm{C}, 16,000 \times \mathrm{g}$ 에서 20 분간 원심 분리 (Gyrozen, Seoul, Korea)하여 세포막 성분 등을 제거하였다.

원심 분리하여 얻은 supernatant는 BCA kit (Thermo Fisher Scientific)로 정량하였으며, 총 $20-30 \mu \mathrm{g} / \mathrm{mL}$ 의 단백질을 $10 \%$ 의 sodium dodecyl sulfate-polyacrylamide gel electrophoresis를 통 해 $110 \mathrm{~V}$ 로 1 시간 30 분간 전기 영동하여 분리하였다. 분리된 단백질은 transfer cell 기기(Hofer.)를 이용하여 PVDF membrane (Millipore Corp, Bedford, MA, USA)으로 $60 \mathrm{~V}$ 로 2시간 30분 간 transfer한 후 실온에서 1시간동안 $5 \% \mathrm{BSA}$ (in TBST) 용 액으로 blocking하였다. Blocking이 끝난 membrane에 COL1A2, MMP-1, MMP-9, TIMP-1, $\beta$-actin antibody를 사용하여 $4{ }^{\circ} \mathrm{C}$ 에서 over night 한 후, TBST buffer를 이용하여 3회 세척하였 다. Goat anti-mouse $\operatorname{IgG}$ secondary antibody를 1시간동안 반 응시킨 후 TBST buffer를 이용하여 3회 세척하였으며, ECL kit (Millipore Corp.)와 반응시켜 Azure Biosystems (C300, Azure Biosystems inc., Dublin, CA, USA)를 이용하여 가시화 및 정량을 하였다. 
Table 1 The primers sequence of real-time PCR for anti-photoaging activity

\begin{tabular}{|c|c|c|c|c|}
\hline Factors & Accession & primer & Sequence $\left(5^{\prime}-3^{\prime}\right)$ & Amplicon (bp) \\
\hline \multirow{2}{*}{ COL1A2 } & \multirow{2}{*}{ NM_000089.3 } & Forward & AGAAACACGTCTGGCTAGGAG & \multirow{2}{*}{105} \\
\hline & & Reverse & GCATGAAGGCAAGTTGGGTAG & \\
\hline \multirow{2}{*}{ MMP-1 } & \multirow{2}{*}{ NM_002421.4 } & Forward & TGGGAGGCAAGTTGAAAAGC & \multirow{2}{*}{135} \\
\hline & & Reverse & CATCTGGGCTGCTTCATCAC & \\
\hline \multirow{2}{*}{ MMP-9 } & \multirow{2}{*}{ NM_004994.3 } & Forward & CCTGGGCAGATTCCAAACCT & \multirow{2}{*}{172} \\
\hline & & Reverse & GTACACGCGAGTGAAGGTGA & \\
\hline \multirow{2}{*}{ HAS2 } & \multirow{2}{*}{ NM_005328.3 } & Forward & GAGGACGACTTTATGACCAAGAGC & \multirow{2}{*}{121} \\
\hline & & Reverse & TAAGCAGCTGTGATTCCAAGGAGG & \\
\hline \multirow{2}{*}{ TGF-, } & \multirow{2}{*}{ NM_000660.6 } & Forward & CAATTCCTGGCGATACCTCAG & \multirow{2}{*}{86} \\
\hline & & Reverse & GCACAACTCCGGTGACATCAA & \\
\hline \multirow{2}{*}{ TIMP-1 } & \multirow{2}{*}{ NM_003254.3 } & Forward & CTTCTGCAATTCCGACCTCGT & \multirow{2}{*}{79} \\
\hline & & Reverse & ACGCTGGTATAAGGTGGTCTG & \\
\hline \multirow{2}{*}{ GAPDH } & \multirow{2}{*}{ NM_008084.3 } & Forward & TGCACCACCAACTGCTTAGC & \multirow{2}{*}{87} \\
\hline & & Reverse & GGCATGGACTGTGGTCATGAG & \\
\hline
\end{tabular}

Table 2 Real-time PCR conditions for photoaging-related factors

\begin{tabular}{|c|c|}
\hline Factors & Real-time PCR condition \\
\hline COL1A2 & $95{ }^{\circ} \mathrm{C}$ for $5 \mathrm{~min}$, followed by undergoing 40 cycles of $95^{\circ} \mathrm{C}$ for $10 \mathrm{~s}, 60^{\circ} \mathrm{C}$ for $20 \mathrm{~s}$, followed by each $95,60,95{ }^{\circ} \mathrm{C}$ for $15 \mathrm{~s}$ \\
\hline MMP-1 & $95{ }^{\circ} \mathrm{C}$ for $5 \mathrm{~min}$, followed by undergoing 40 cycles of $95^{\circ} \mathrm{C}$ for $10 \mathrm{~s}, 60^{\circ} \mathrm{C}$ for $20 \mathrm{~s}$, followed by each $95,60,95{ }^{\circ} \mathrm{C}$ for $15 \mathrm{~s}$ \\
\hline MMP-9 & $95{ }^{\circ} \mathrm{C}$ for $5 \mathrm{~min}$, followed by undergoing 40 cycles of $95^{\circ} \mathrm{C}$ for $10 \mathrm{~s}, 60^{\circ} \mathrm{C}$ for $20 \mathrm{~s}$, followed by each $95,60,95{ }^{\circ} \mathrm{C}$ for $15 \mathrm{~s}$ \\
\hline HAS2 & $95{ }^{\circ} \mathrm{C}$ for $5 \mathrm{~min}$, followed by undergoing 40 cycles of $95{ }^{\circ} \mathrm{C}$ for $10 \mathrm{~s}, 60^{\circ} \mathrm{C}$ for $20 \mathrm{~s}$, followed by each $95,60,95{ }^{\circ} \mathrm{C}$ for $15 \mathrm{~s}$ \\
\hline TGF-, & $95{ }^{\circ} \mathrm{C}$ for $5 \mathrm{~min}$, followed by undergoing 40 cycles of $95^{\circ} \mathrm{C}$ for $10 \mathrm{~s}, 60^{\circ} \mathrm{C}$ for $20 \mathrm{~s}$, followed by each $95,60,95{ }^{\circ} \mathrm{C}$ for $15 \mathrm{~s}$ \\
\hline TIMP-1 & $95{ }^{\circ} \mathrm{C}$ for $5 \mathrm{~min}$, followed by undergoing 40 cycles of $95^{\circ} \mathrm{C}$ for $10 \mathrm{~s}, 60^{\circ} \mathrm{C}$ for $20 \mathrm{~s}$, followed by each $95,60,95{ }^{\circ} \mathrm{C}$ for $15 \mathrm{~s}$ \\
\hline GAPDH & $95{ }^{\circ} \mathrm{C}$ for $5 \mathrm{~min}$, followed by undergoing 40 cycles of $95{ }^{\circ} \mathrm{C}$ for $10 \mathrm{~s}, 60^{\circ} \mathrm{C}$ for $20 \mathrm{~s}$, followed by each $95,60,95{ }^{\circ} \mathrm{C}$ for $15 \mathrm{~s}$ \\
\hline
\end{tabular}

Real-time PCR을 이용한 photoaging-related factors (COL1A2, MMP-1, MMP-9, HAS2, TGF- $\beta$, TIMP-1) 발현량 측정

UVB로 자극된 CCD986sk 세포의 photoaging-related factors 발현량 측정은 $100 \times 20 \mathrm{~mm}$ culture dish에 $1 \times 10^{6}$ cells $/ \mathrm{mL}$ 이 되도록 분주하고 24시간 전 배양하고, 무혈청 배지로 교환한 후, 5시간 이상 cell starvation하였다. 세포에 UVB $\left(24 \mathrm{~mJ} / \mathrm{cm}^{2}\right)$ 자 극과 추출물과 정제물을 농도별로 처리하여 48시간 재 배양하 고 PBS로 세척하였다. photoaging-related factors의 mRNA 발 현량을 비교 분석하기 위해 total RNA를 GeneAll ${ }^{\mathbb{R}}$ Ribospin RNA extraction kit (GeneAll Biotechnology Co, Seoul, Korea) 을 사용하여 추출하였다. 추출한 total RNA는 $-80{ }^{\circ} \mathrm{C}$ 에 보관하 여 사용하였으며, qPCRBIO cDNA synthesis Kit (PCR Biosystems, London, $\mathrm{UK}$ )을 이용하여 $\mathrm{cDNA}$ 를 합성하였다. 합성된 $\mathrm{cDNA}$ 는 Tris/EDTA buffer를 첨가하여 $1 / 2$ 로 희석해서 사용하였다. 합성된 cDNA $1 \mu \mathrm{L}$, Real time PCR master mix $5 \mu \mathrm{L}$ (GeneAll Biotechnology Co.), primer 및 nuclease-free water를 넣고 PCRmax Eco 48 real-time PCR system (PCRmax, Staffordshire, UK)을 이용하여 유전자별 mRNA 발현량을 실시 간 분석하였으며, PCR condition과 primer sequence는 Table 1,2 에 기재하였다.

\section{통계처리}

실험결과는 3 번 이상 반복하여 측정한 후 평균값으로 나타내었
으며, 실험결과의 통계분석은 SPSS 23 (Statistical Package for Social Science, Chicago, IL, USA)의 Duncan's multiple range test one way ANOVA를 이용하여 시료 간의 유의성 검정 $(p<0.05, p<0.01)$ 을 하였다.

\section{결과 및 고찰}

\section{Fibroblast cell line MTT 측정}

$\mathrm{GBE}$ 의 CCD986sk cell에 대한 독성을 확인하기 위해 MTT assay를 이용하여 세포 생존율을 측정한 결과 Fig. 1에서와 같 다. $\mathrm{GBE}$ 를 농도별 $(100,200,300,400,500 \mu \mathrm{g} / \mathrm{mL})$ 로 처리하 였을 때 농도가 증가하여도 세포 생존율이 98.09-95.70\%로 $95 \%$ 이상으로 나타났으며, $500 \mu \mathrm{g} / \mathrm{mL}$ 의 고농도로 처리하였을 때 세포 생존율이 $95 \%$ 이상으로 확인되어 고농도의 $\mathrm{GBE}$ 처 리 시 세포 생존율에 크게 영향을 미치지 않는 것을 확인할 수 있었다.

위의 결과에 따라 GBE가 CCD986sk cell에 대한 세포독성을 가지지 않음을 확인하여 $500 \mu \mathrm{g} / \mathrm{mL}$ 을 최고 농도로 설정하여 추 후 western blot 및 real-time PCR 측정 실험을 진행하였다.

Western blot을 이용한 COL1A2 protein 발현량 측정

인체 피부의 기능적인 특성은 피부에서 가장 풍부하게 존재하 


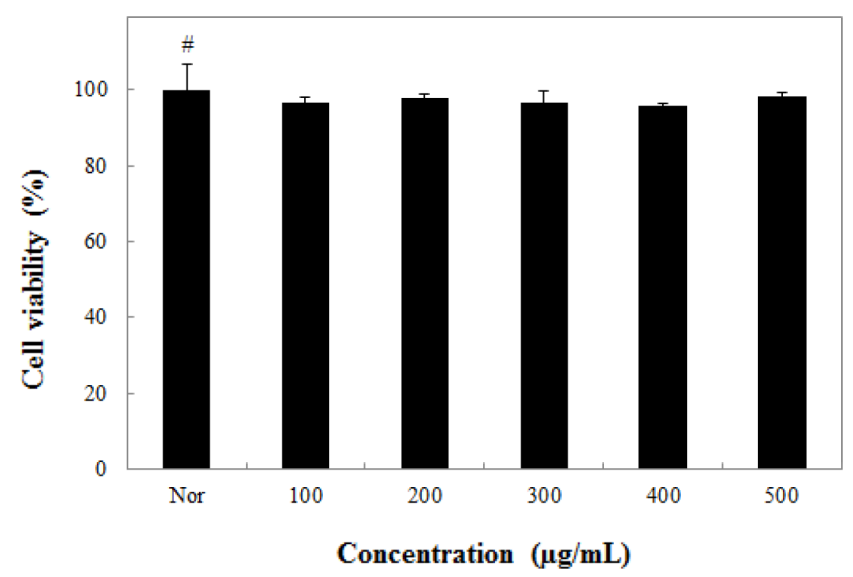

Fig. 1 Effect of GBE on cell viability in CCD986sk fibroblasts in MTT assay. CCD986sk fibroblast $\left(5 \times 10^{4}\right.$ cells $\left./ \mathrm{mL}\right)$ were incubated with various concentrations $(100-500 \mu \mathrm{g} / \mathrm{mL})$ for $48 \mathrm{~h}$. The values are mean $\pm \mathrm{SD}$ of three independent experiments $(\mathrm{n}=3)$. $\# p<0.05$ compared with Nor group

는 구조 단백질인 collagen의 상태와 관련이 깊으며, collagen은 피부에 강도와 장력을 부여하여 외부의 자극 등으로부터 피부 를 보호하는 역할을 한다. Collagen의 감소는 피부의 노화 및 주름생성에 밀접하게 관여하는 성분으로 알려져 있다[15]. 또한 인체 내의 collagen의 합성 및 분해과정은 적절하게 조절되며, 노화가 진행되면서 collagen의 양이 감소하고 피부가 자외선에 노출되면 기질 단백질 분해효소인 MMPs의 발현이 촉진된다 [7,16]. 지금까지 약 20종의 MMPs가 발견되었는데 MMP는 기 저막과 세포외기질의 분해에 관여하는 아연을 포함하는 단백질 분해 효소로서 구조 및 기능적 특성에 따라 collagenase, gelatinase, stromelysin, matrilysin 및 membrane type-MMP 등으로 구분 된다[17]. 피부에서의 collagen 합성은 고령화에 따른 내인성 노 화 및 자외선 노출에 의한 광노화와 관련이 있다. $\mathrm{GBE}$ 의 $\mathrm{COL} 1 \mathrm{~A} 2$ protein 발현에 미치는 영향을 확인하기 위해 $\mathrm{UVB}$ 에 의해 자극된 CCD986sk cell에 $\mathrm{GBE}$ 를 농도별 $(100,300,500$ $\mu \mathrm{g} / \mathrm{mL}$ )로 처리하여 발현량을 측정한 결과 Fig. 2에서와 같이 $55.87,65.40,100.00 \%$ 의 COL1A2 발현량을 나타내어 $500 \mu \mathrm{g} /$ $\mathrm{mL}$ 의 고농도에서 $100.00 \%$ 로 UVB 자극을 주지 않은 normal (Nor)군의 상태와 같은 COL1A2 합성 효과를 확인하였다.

\section{Western blot을 이용한 MMP-1, MMP-9, TIMP-1 protein 발현량 측정}

피부의 노화가 진행됨에 따라 피부 내의 MMP-1의 활성이 증 가하게 되고, 피부의 collagen 합성이 감소하여 피부 탄력 감소 와 주름을 유발한다[18,19]. MMP-9은 기저막을 형성하는 제4 형 아교질섬유를 분해하는 효소로 알려져 있으며, 이러한 용해 성 MMPs는 비활성형으로 분비되어 $\mathrm{N}$-말단 전구영역이 분리된 다음 활성화되는데 여러 단백분해효소들이 이 전구효소의 활성 화에 관여한다. 활성형 MMPs는 주로 $\mathrm{TIMPS}$ 에 의해 억제된다 [20]. TIMPs는 지금까지 주로 4군이 알려져 있으며, TIMP-1은 MMP-9, TIMP-2는 MMP-2를 각각 대항함으로써 피부 세포 내 에서 염증이나 주름 예후 인자들과 연관성을 보였다는 보고가

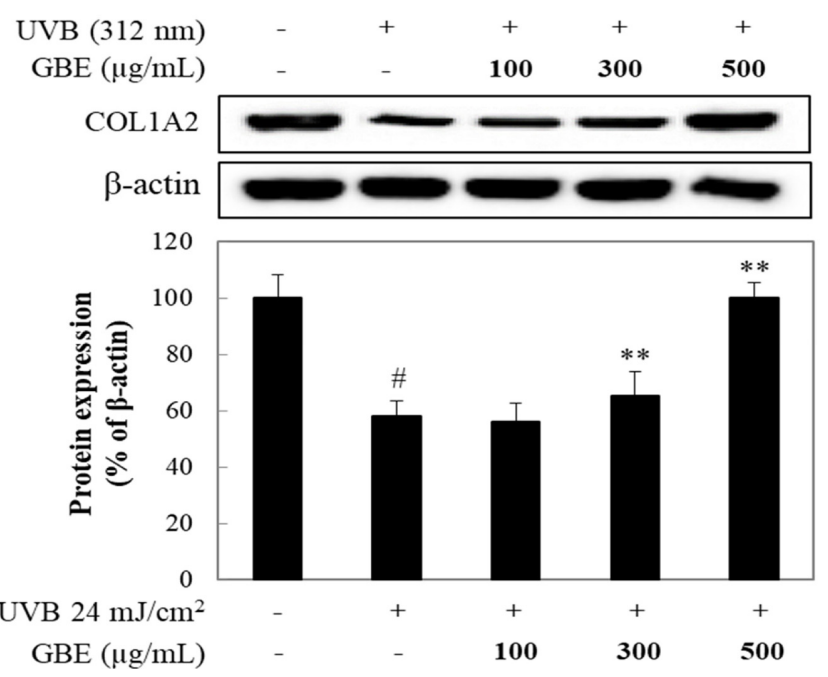

Fig. 2 Effect of GBE the protein expression of COL1A2 in stimulated CCD986sk fibroblasts with UVB. CCD986sk fibroblast $\left(1 \times 10^{5}\right.$ cells $\left./ \mathrm{mL}\right)$ were treated with UVB $\left(24 \mathrm{~mJ} / \mathrm{cm}^{2}\right)$ and, $100-500 \mu \mathrm{g} / \mathrm{mL}$ of dissolved in D.W was added, and the cells were further incubated for $48 \mathrm{~h}$. Nor group were obtained in the absence of UVB. Con group treated only UVB. The values are mean $\pm \mathrm{SD}$ of three independent experiments $(\mathrm{n}=3) .{ }^{*} p<0.05$ compared with Con group, $* * p<0.01$ compared with Con group

\section{있다[21].}

GBE의 MMP-1, MMP-9, TIMP-1 protein 발현에 미치는 영 향을 확인하기 위해 UVB에 의해 자극된 CCD986sk cell에 $\mathrm{GBE}$ 를 농도별 $(100,300,500 \mu \mathrm{g} / \mathrm{mL})$ 로 처리하여 발현량을 측 정한 결과 MMP- 1 의 경우에는 Fig. $3 \mathrm{~A}$ 에서와 같이 99.08 , $75.69,73.36 \%$ 의 발현량을 나타내었으며, $500 \mu \mathrm{g} / \mathrm{mL}$ 의 고농도 에서 $26.64 \%$ 의 억제 효과를 나타내었고, MMP-9의 경우에는 Fig. 3B에서와 같이 $60.77,46.27,32.98 \%$ 의 발현량을 나타내었 으며, $500 \mu \mathrm{g} / \mathrm{mL}$ 의 고농도에서 $67.02 \%$ 의 억제 효과를 나타내 었다. TIMP-1의 경우에는 Fig. $3 \mathrm{C}$ 에서와 같이 $64.16,60.80$, $84.08 \%$ 의 TIMP-1 발현량을 나타내었고, $500 \mu \mathrm{g} / \mathrm{mL}$ 의 고농도에 서 $84.08 \%$ 로 UVB 자극만 처리한 control (Con)군의 $40.59 \%$ 에 비해 우수한 TIMP-1 생성 효과를 확인하였다. UVB에 의해 자 극된 MMP-1, MMP-9 protein 모두 농도 의존적으로 발현량이 감소하였으며, COL1A2, TIMP-1 protein의 경우 농도 의존적으 로 발현량이 유의적으로 증가하는 것을 확인하였다.

위의 결과에 따라 GBE가 MMP-1 protein을 억제하였으며, $\mathrm{MMP}-1$ 의 활성억제에 의해 $\mathrm{COL} 1 \mathrm{~A} 2$ 의 합성량이 증가되는 것 을 확인하였다. 따라서 GBE가 type I collagenase group의 MMP-1 억제와 이와 관련된 COL1A2 합성에 모두 관여한다고 판단되었다. 또한 gelatin 분해와 type IV collagenase로 알려진 MMP-9의 억제, MMPs의 tissue inhibitor로 알려진 glycoprotein 인 TIMP-1의 생성에도 관여하는 것을 확인하였으며, 주름과 관 련된 또 다른 유전자에도 영향을 미칠 것으로 예상되었다. 따 라서 $\mathrm{GBE}$ 의 경우와 같이 collagen 대사를 조절하는 소재의 탐 색은 자외선으로부터 유도되는 피부 노화를 예방하고 치료하는 데 효과적인 접근 방법으로 판단되고 있다. 
(A)

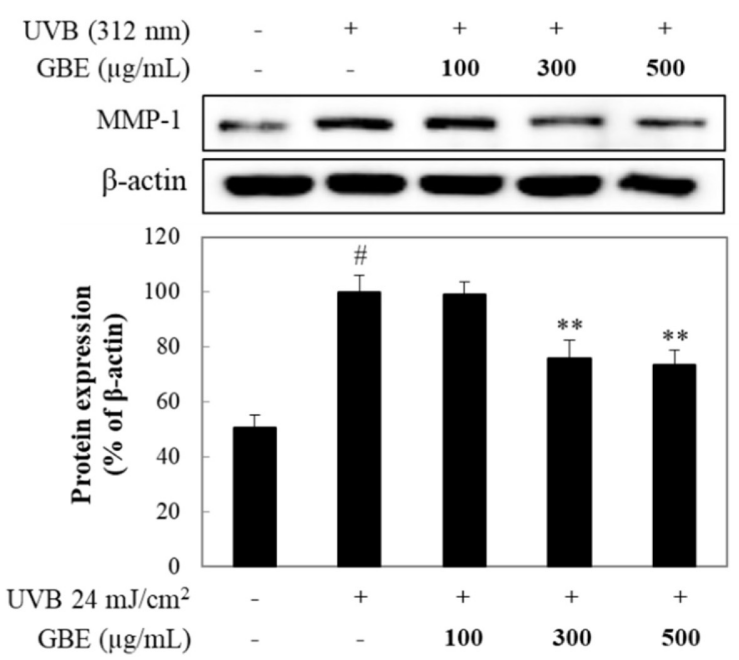

(C)

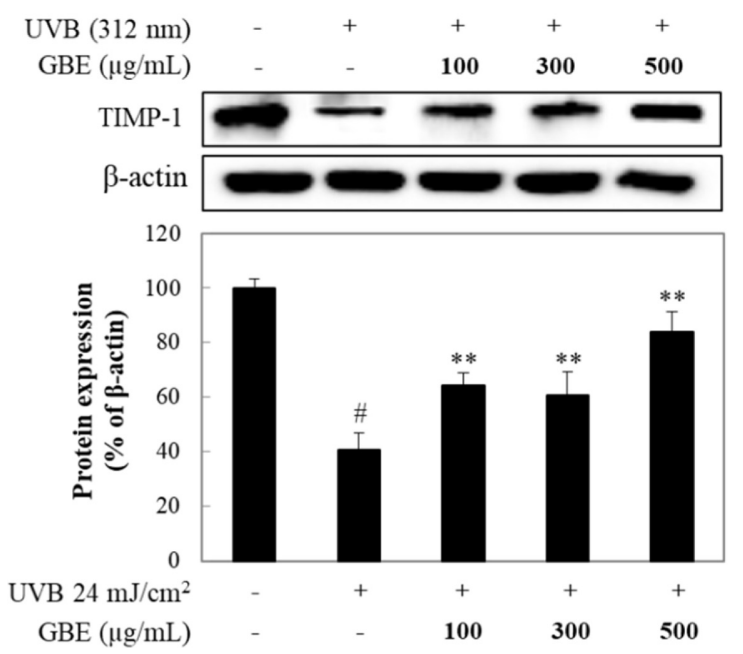

Real-time PCR을 이용한 photoaging-related factors (COL1A2, MMP-1, MMP-9, HAS2, TGF- $\beta$, TIMP-1) 발현량 측정

노화가 진행될수록 피부를 구성하는 물질인 collagen, elastin, hyaluronic acid 등 구조 단백질을 생성하는 능력이 감소한다 [22]. 피부에 있어 collagen은 신체 곳곳에 존재하는 대표적인 섬유상 단백질로서 14 개의 type이 존재하며 이 중 피부에는 type I collagen이 주로 존재한다[23]. Type I collagen은 피부 의 진피, 힘줄, 빼, 그리고 치아 등에 존재하며 조직의 탄력을 유지하는데 중요한 역할을 한다[24]. Collagen은 두 개의 $\alpha 1$ 사 슬과 한 개의 $\alpha 2$ 사슬이 3중 나선 형태로 꼬여서 생성되며 이 사슬들은 각각 COL1A1, COL1A2 유전자로부터 발현된다[25]. 피부 노화는 진피섬유아세포의 작용이 특정 요인에 의해 이상 이 생기는 것으로, 진피섬유아세포의 기능 이상은 collagen의 생 성 저해와 collagen 분해 효소인 MMPs의 활성 증가로 이어지 게 된다. MMPs는 진피층으로 분비되어 collagen의 분해를 촉 진하여 주름 생성과 탄력의 감소를 유도한다[26,27]. 섬유아세 포에서 생성되는 MMP-1, MMP-9은 type I, II, III collagen을
(B)

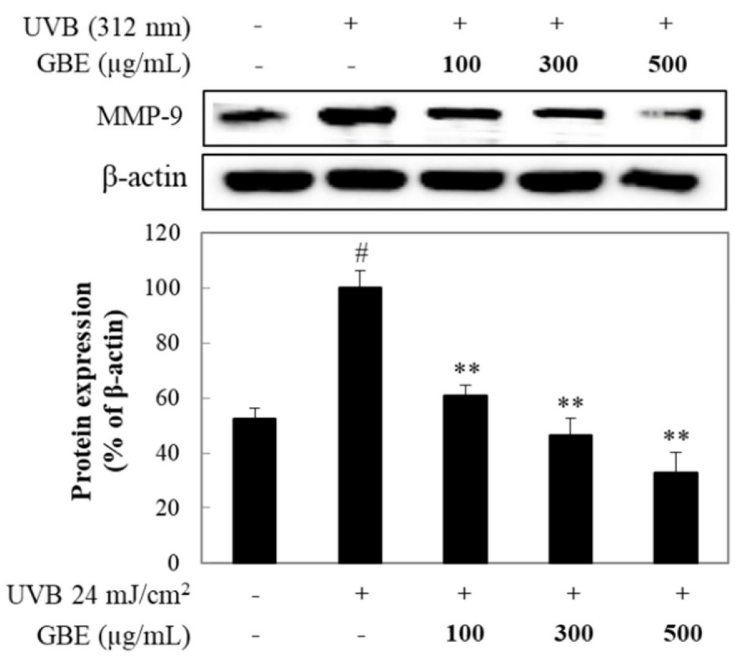

Fig. 3 Effect of GBE the protein expression of MMP-1 (A), MMP-9 (B), TIMP-1 (C) in stimulated CCD986sk fibroblasts with UVB. CCD986sk fibroblast $\left(1 \times 10^{5}\right.$ cells $\left./ \mathrm{mL}\right)$ were treated with UVB $\left(24 \mathrm{~mJ} / \mathrm{cm}^{2}\right)$ and, 100 $500 \mu \mathrm{g} / \mathrm{mL}$ of dissolved in D.W was added, and the cells were further incubated for $48 \mathrm{~h}$. Nor group were obtained in the absence of UVB. Con group treated only UVB. The values are mean $\pm \mathrm{SD}$ of three independent experiments $(\mathrm{n}=3) .{ }^{*} p<0.05$ compared with Con group, ${ }^{* *} p<0.01$ compared with Con group

분해하는 작용을 한다[28]. MMPs의 활성을 조절하는 인자로 알려진 TIMPs는 MMPs와 비 공유적인 결합을 하여 MMPs의 기능을 억제하는 것으로 알려져 있고, TIMP-1은 MMP-9과, TIMP-2는 MMP-2와 각각 결합하여 세포 간 기질의 파괴와 재 형성 간의 균형을 조절하는 역할을 한다[29]. 세포생존, 세포분 화, 세포외기질 합성 등 다양한 생리학적 기전에 관여하는 대 표적인 다기능 사이토카인인 TGF- $\beta$ 는 UVB에 의하여 증가된 $\mathrm{ROS}$ 에 의해 저해되며, TGF- $\beta$ 의 활성화는 MMPs와 type I pro-collagen 발현에 관여하는 것으로 알려져 있다[30].

GBE의 photoaging-related factors (COL1A2, MMP-1, MMP9, HAS2, TGF- $\beta$, TIMP-1) 발현량을 확인하기 위해 UVB에 의해 자극된 CCD986sk cell에 GBE를 농도별 $(100,300,500$ $\mu \mathrm{g} / \mathrm{mL}$ )로 처리하여 발현량을 측정한 결과 Fig. $4 \mathrm{~A}$ 에서와 같이 $0.48,0.62,0.68$ 의 COL1A2 발현량을 나타내어 $100-500 \mu \mathrm{g} / \mathrm{mL}$ 의 모든 농도에서 UVB 자극만 처리한 Con군의 0.34 에 비해 높은 COL1A2 생성량을 나타내었다. MMP-1의 경우에는 Fig. $4 \mathrm{~B}$ 에서와 같이 $0.84,0.61,0.59$ 의 발현량을 나타내어 $500 \mu \mathrm{g} /$ 

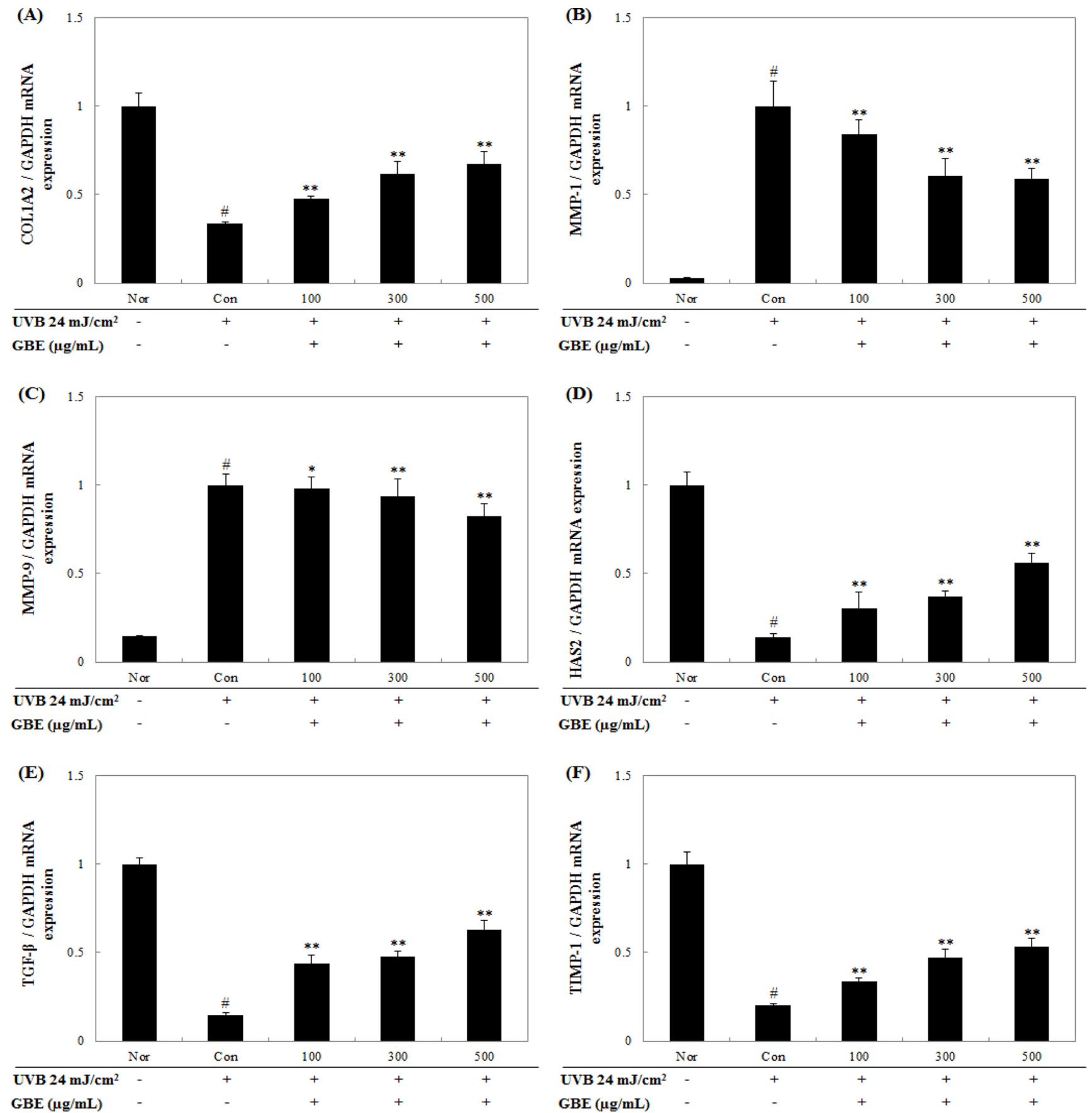

Fig. 4 Effect of GBE on mRNA expression in CCD986sk fibroblast stimulated with UVB. CCD986sk fibroblast $\left(1 \times 10^{6}\right.$ cells $\left./ \mathrm{mL}\right)$ were treated with UVB $\left(24 \mathrm{~mJ} / \mathrm{cm}^{2}\right)$ and, various concentrations $(100-500 \mu \mathrm{g} / \mathrm{mL})$, were added and the cells were further incubated for $48 \mathrm{~h}$. The mRNA expression of the photoaging-related factors COL1A2 (A), MMP-1 (B), MMP-9 (C), HAS2 (D), TGF- $\beta$ (E), TIMP-1 (F) were measured by real-time PCR. Relative mRNA expression levels were normalized to GAPDH. Nor group measurements were obtained in the absence of UVB. Con group treated only UVB. The values are mean $\pm \mathrm{SD}$ of three independent experiments $(\mathrm{n}=3)$. ${ }^{*} p<0.05$ compared with Con group, ${ }^{*} p<0.05,{ }^{* *} p<0.01$ compared with Con group

$\mathrm{mL}$ 의 고농도에서 Con군과 비교하였을 때 MMP-1의 효과적인 억제 효과를 확인할 수 있었으며, MMP-9의 경우에는 Fig. 4C 에서와 같이 $0.98,0.94,0.83$ 의 발현량을 나타내어 $500 \mu \mathrm{g} / \mathrm{mL}$ 의 고농도에서 Con군과 비교하였을 때 MMP-9의 억제 효과를 확인하였다. $\mathrm{HAS} 2$ 의 경우에는 Fig. $4 \mathrm{D}$ 에서와 같이 $0.30,0.37$,
0.56 의 발현량을 나타내어 농도의존적으로 유의적으로 상승하는 결과를 나타내었다. TGF- $\beta$ 의 경우에는 Fig. $4 \mathrm{E}$ 에서와 같이 $0.44,0.48,0.63$ 의 발현량을 나타내어 TGF- $\beta$ 가 농도의존적으로 발현량이 증가하는 결과를 나타내었다. TIMP-1의 경우에는 Fig. $4 \mathrm{~F}$ 에서와 같이 $0.34,0.47,0.53$ 의 발현량을 나타내어 우수한 
MMPs 조절 효과를 나타내었다. 위의 결과에 따라 UVB에 의 해 자극된 photoaging-related factors 모두 유의적으로 발현량이 감소하거나 증가하는 것을 확인하였으며, UVB 자극만 처리한 Con군의 발현량과 비교하였을 때 유의적으로 더 우수한 효과를 나타내었다. 또한 GBE가 MMP-1, MMP-9을 효과적으로 억제 하였으며, MMPs와 type I pro-collagen 발현에 관여하는 조절 인자인 TIMP-1과 TGF- $\beta$ 의 발현량이 증가함에 따라 COL1A2 의 생성량이 증가하는 것을 확인할 수 있었다. 그리고 피부를 구성하는 구조 단백질 중 하나인 hyaluronic acid 생성에 관여 하는 HAS2의 발현량 증가를 확인하였다. 따라서 $\mathrm{GBE}$ 가 주름 생성에 영향을 미치는 인자와 주름개선에 영향을 미치는 인자 모두에 관여한다고 판단되었다.

\section{초 록}

본 연구에서는 한국에서 육종한 신육성품종 그린볼 사과 껍질 추출물 $(\mathrm{GBE})$ 이 피부 광노화 인자조절에 대한 억제효과를 확인 하였다. 피부에서 광노화 인자 조절에 대한 억제 효과를 확인 하기 위해 CCD986sk fibrobalst cell에 UVB로 광노화를 유도 시킨 후 세포에 $\mathrm{GBE}$ 를 처리하였다. 광노화 인자 조절 효과를 측정한 결과 GBE가 COL1A2, MMP-1, MMP-9, TIMP-1 단 백질 발현량에서 UVB에 의해 자극된 MMP-1, MMP-9 단백질 합성을 억제하였으며, COL1A2, TIMP-1 단백질의 경우 발현량 이 유의적으로 증가하는 것을 확인하였다. Photoaging-related factors인 COL1A2, MMP-1, MMP-9, HAS2, TGF- $\beta$, TIMP-1 의 mRNA 발현량을 측정한 결과 $\mathrm{GBE}$ 에 의해 MMP-1, MMP9 단백질 발현을 효과적으로 억제하였으며, MMPs와 type procollagen 발현에 관여하는 조절인자인 TIMP-1과 TGF- $\beta$ 의 발현 량이 증가함에 따라 $\mathrm{COL} 1 \mathrm{~A} 2$ 의 생성량이 증가하는 것을 확인 할 수 있었다. 또한 피부를 구성하는 구조 단백질 중 하나인 hyaluronic acid 생성에 관여하는 HAS2의 발현량 증가도 확인 하였다. 따라서 $\mathrm{GBE}$ 는 광노화의 인자 억제 조절에 대한 우수 한 효능을 가졌으며, 피부 노화를 예방하는 기능성 소재로서 활 용이 가능할 것으로 판단되었다.

Keywords 그린볼 - 광노화 - 신육성품종사과 - 추출물 - CCD986sk fibroblast

\section{References}

1. Lee HY, Kim GJ, Kim YS, Lee SN, Lee SO (2007) Skin science. Koonja Publisher, Paju

2. Yoon Y, Bae S, An S, Choe YB, Ahn KJ, An IS (2013) Effects of ultraviolet radiation on the skin and skin cell signaling pathways. Asian Journal of Beauty and Cosmetology 11: 417-426

3. Puizina-Iviæ N (2008) Skin aging. Acta Dermatovenerol Alp Pannonica Adriat 17: 47-54

4. Kim YA, Kim DH, Yu JM, Park CB, Park TS, Park BJ (2017) Antiwrinkle effects of extracts and solvent fractions from Nymphoides peltata on CCD-986sk. J Appl Biol Chem 60: 357-362

5. Jenkins G (2002) Molecular mechanisms of skin ageing. Mech Ageing Dev 123: $801-810$
6. Kim SN, Lee CM, Lee SH, Kim YC (2013) Inhibitory efficacy of water soluble extracts from green, white and black teas on MMP-2 activity and MMP-1 gene expression in human dermal fibroblasts. J Invest Cosmet 9: 21-26

7. Chung JH, Seo JY, Choi HR, Lee MK, Youn CS, Rhie GE, Cho KH, Kim KH, Park KC, Eun HC (2001) Modulation of skin collagen metabolism in aged and photoaged human skin in vivo. J Invest Dermatol 117: 1218-1224

8. Chung JH, Hanft VN, Kang S (2003) Aging and photoaging. J American Acad Dermatol 49: 690-697

9. Kwon SI, Kim JI, Kim MJ, Paek PN, Shin YU, Hwang JH, Kang SJ, Kim DI, Choi C, Kang IK (2011) 'Hongan', a New Mid-Season Apple Cultivar. Kor J Hort Sci Technol 29: 655-658

10. Kwon SI, Park JT, Lee JW, Kim MJ, Kim JH (2015) 'Picnic', a New Mid-season Apple Cultivar with Medium Size and Good Taste. Kor J Hort Sci Technol 33: 784-788

11. Kwon OJ (2016) Antioxidant and tyrosinase inhibitory activities of immature fruits of Malus pumila cv. Fuji. Korean J Food Preserv 23: 585-590

12. Kwon SI, Kwon YS, Park JT, Kim MJ, Kim JH (2016) New Columnar Apple Variety 'Tinkerbell' for Pollenizer. Protected Horticulture and Plant Factory 25: 173-176

13. Yun HJ, Lim SY, Hur JM, Jeong JW, Yang SH, Kim DH (2007) Changes of functional compounds in, and texture characteristics of, apples, during post-irradiation storage at different temperatures. Korean J Food Preserv 14: 239-246

14. Carmichael J, DeGraff WG, Gazdar AF, Minna JD, Mitchell JB (1987) Evaluation of a tetrazolium based semiautomated colorimetric assay: assessment of chemosensitivity testing. Cancer Research 47: 936-942

15. Kavitha O, Thampan RV (2008) Factors influencing collagen biosynthesis. J Cell Biochem 104: 1150-1160

16. Scharffetter K, Wlaschek M, Hogg A, Bolsen K, Schothorst A, Goerz G, Krieg T, Plewig G (1991) UVA irradiation induces collagenase in human dermal fibroblasts in vitro and in vivo. Arch Dermatol Res 283: 506-511

17. Visse R, Nagase H (2003) Matrix metalloproteinases and tissue inhibitors of metalloproteinases: structure, function, and biochemistry. Circ Res 92: 827-839

18. Fisher GJ, Datta SC, Talwar HS, Wang ZQ, Varani J, Kang S, Voorhees JJ (1996) Molecular basis of sun-induced premature skin ageing and retinoid antagonism. Nature 379: 335-339

19. Varani J, Warner RL, Gharaee-Kermani M, Phan SH, Kang S, Chung JH, Wang ZQ, Datta SC, Fisher GJ, Voorhees JJ (2000) Vitamin A antagonizes decreased cell growth and elevated collagen-degrading matrix metalloproteinases and stimulates collagen accumulation in naturally aged human skin. J Invest Dermatol 114: 480-486

20. Curran S, Murray GI (1999) Matrix metalloproteinases in tumor invasion and metastasis. J Pathol 189: 300-308

21. Ellenrieder V, Alber B, Lacher U, Hendler SF, Menke A, Boeck W, Wagner M, Wilda M, Friess H, Büchler M, Adler G, Gress TM (2000) Role of MT-MMPs and MMP-2 in pancreatic cancer progression. Int J Cancer 85: 14-20

22. Brenneisen P, Sies H, Scharffetter-Kochanek K (2002) Ultraviolet-B irradiation and matrix metalloproteinases:from induction via signaling to initial events. Ann NY Acad Sci 973: 31-43

23. Uitto J, Olsen DR, Fazio MJ (1989) Extracellular matrix of the skin. J Invest Dermatol 92: 61S-77S

24. Souza RR de (2002) Aging of myocardial collagen. Biogerontology 3: 325-335

25. Paul S (2011) Fish bone chemistry and ultrastructure: implications for taphonomy and stableisotope analysis. J Archaeol Sci 38: 3358-3372

26. Fisher GJ, Datta SC, Talwar HS, Wang ZQ, Varani J, Kang S, Voorhees JJ (1996) Molecular basis of sun-induced premature skin ageing and retinoid antagonism. Nature 379: 335-339

27. Kang S, Chung JH, Lee JH, Fisher GJ, Wan YS, Duell EA, Voorhees JJ (2003) Topical N-acetyl cysteine and genistein prevent ultraviolet-light- 
induced signaling that leads to photoaging in human skin in vivo. $\mathrm{J}$ Invest Dermatol 120: 835-841

28. Lee J, Jung E, Lee J, Huh S, Hwang CH, Lee HY, Kim EJ, Cheon JM, Hyun CG, Kim YS, Park D (2006) Emodin inhibits TNF alpha-induced MMP-1 expression through suppression of activator protein-1 (AP-1). Life Sci 79: 2480-2485
29. Johnson MD, Kim HR, Chesler L, Tsao-Wu G, Bouck N, Polverini PJ (1994) Inhibition of angiogenesis by tissue inhibitor of metalloproteinase. J Cell Physiol 160: 194-202

30. Oh JH (2019) Protective Effect of Portulaca oleracea L. against Ultraviolet B-induced Skin Photoaging in Human Keratinocytes. University of Silla, Busan, Korea. pp 118-121 